\title{
Analysis on the Characteristics and Constraints of the Development of Cross-border E-Commerce Agricultural Trade
}

\author{
Fengli Fu ${ }^{1}$ \\ ${ }^{1}$ Nanchang University Gongqing College, Gongqing City, Jiangxi, 332020
}

Keywords: agricultural trade; cross-border e-commerce; characteristics and constraints

\begin{abstract}
Cross-border e-commerce trade in agricultural products can reduce the intermediate links in agricultural products trade and reduce the cost of circulation of agricultural products trade, which is conducive to the improvement of China's agricultural product trade efficiency. This paper first summarizes the development characteristics of China's cross-border agricultural trade, and then analyzes and discusses the factors that restrict China's cross-border e-commerce trade in agricultural products. Based on this, it makes recommendations for the development of cross-border agricultural trade.
\end{abstract}

\section{Introduction}

As a traditional agricultural country, China has a rich variety of agricultural products. Trade in agricultural products not only accounts for a relatively large proportion in China's domestic commodity trading system, but also accounts for a large share in China's participation in the international trading system. Due to the adverse effects of the financial crisis in 2008 and the slowdown in macroeconomic growth, China's international and domestic trade has continued to slump, and agricultural trade has also been affected. There are also many deficiencies in China's traditional trade mode of agricultural products. The channels for agricultural products to participate in international trade are single and the cost is high. How to improve China's agricultural trade system, speed up the transformation and upgrading of China's agricultural trade, drive the development and growth of China's agricultural trade, and improve the competitiveness of China's agricultural trade in the international agricultural trade system are the government's relevant departments need to seriously study.

With the rapid development of the Internet, cross-border e-commerce has also achieved rapid and long-term development. Cross-border e-commerce has unique advantages in reducing trade costs and improving trade flow efficiency. It has extensive applications in China's textile and clothing trade, and electronic product trade. Although agricultural trade is still in its infancy, it is already in practice in some localities. Good results. The use of an e-commerce platform to promote the development of agricultural trade, give play to the local characteristics of agricultural products, and promote the transformation and upgrading of agricultural trade have also been valued by the Chinese government. This article first summarizes the development characteristics of China's cross-border agricultural trade, and then analyzes and discusses the factors that restrict China's cross-border e-commerce trade in agricultural products. Based on this, it makes recommendations for the development of cross-border agricultural trade.

\section{Characteristics of the Development of Cross-border E-commerce Trade in Agricultural Products}

Cross-border e-commerce trade in agricultural products refers to a new type of commercial trade mode in which trading entities in different customs areas complete the purchase and sale of agricultural products through related platforms provided by e-commerce, trans-border agricultural products through cross-border logistics, and complete payment and settlement transactions. Compared with the traditional mode of agricultural product trade, cross-border e-commerce has greatly shortened the circulation of agricultural products and greatly improved the efficiency and 
profit of agricultural products trade. From the perspective of the development of cross-border e-commerce agricultural trade in China, it also has the following characteristics:

Since 2012, China's policies and attitudes toward cross-border e-commerce have been highly supported. However, for the issue of cross-border e-commerce among e-commerce companies, retail export goods cannot be refunded or exchanged, and China's General Administration of Customs is specialized. Implementation of the "Manifest Verification, Collective Declaration" management method. Governments at all levels have also noticed the unique advantages of cross-border e-commerce trade development, and have introduced relevant policies to encourage and support their development. With the support of policies, the cross-border e-commerce of agricultural products in China has developed rapidly. Many cross-border e-commerce platforms such as Alibaba, Amazon, eBay, Lanting Tendency, and Dunhuang Net have exerted efforts, and the cross-border trade volume of agricultural products in China has been growing rapidly. situation. Cross-border e-commerce can always find new trading hotspots to promote the development of agricultural products trade. Imported agricultural products such as cross-border fresh produce trade will become a new trading hot spot for cross-border e-commerce in 2013, Jingdong Mall, Tmall Taobao, and No. 1 store. I bought nets, etc. have successively opened overseas agricultural trade channels. In 2014, the Shanghai Free Trade Zone also successively opened cross-border e-commerce platforms for agricultural products such as "tax-receipt.com" and "cross-border-access" to promote the foreign trade of agricultural products. According to the statistics of the General Administration of Customs, in 2013 China's agricultural product trade exports reached US\$67.83 billion, an increase of 7.2\% year-on-year. In 2014, agricultural product trade exports exceeded US\$70 billion. The specific data are shown in Table 1.

Table 1 Import and Export Trade of China's Agricultural Products (Unit: US\$100 million)

\begin{tabular}{|l|l|l|l|l|l|}
\hline Year & Total trade & $\begin{array}{l}\text { Export } \\
\text { volume }\end{array}$ & $\begin{array}{l}\text { Year-on-year } \\
\text { increase and } \\
\text { decrease }\end{array}$ & $\begin{array}{l}\text { Imports of } \\
\text { trade }\end{array}$ & $\begin{array}{l}\text { Year-on-year } \\
\text { increase and } \\
\text { decrease }\end{array}$ \\
\hline 2013 & 1866.9 & 678.3 & $+7.2 \%$ & 1188.7 & $+5.7 \%$ \\
\hline 2014 & 1945.0 & 719.6 & $+6.1 \%$ & 1225.4 & $+3.1 \%$ \\
\hline
\end{tabular}

The U.S. Food Industry Association analyzed the statistical data of China's agricultural trade and concluded that China's import food trade scale will reach 480 billion yuan in 2018. At that time, China will also become the world's largest consumer of imported food, and this will surely be enormous. Stimulate the development of cross-border e-commerce of agricultural products in China.

As China gradually enters the "Internet Plus" era, participants in all aspects of the traditional trade circulation of agricultural products begin to shift to the e-commerce platform. Active participation of direct consumers, individual industrial and commercial households, suppliers, distributors, factories, and foreign trade companies also allows The participants of cross-border e-commerce trade in agricultural products are more diverse. With the help of the Internet, all kinds of information related to agricultural trade can break through time and geographical restrictions, and can be shared with consumers and companies around the world through e-commerce platforms. The interactive channels provided by the e-commerce platform not only help sellers master the distinctive needs of consumers in different geographical areas, but also plan and focus on cross-border transactions of agricultural products, and also enable buyers to contact commodity prices and services of agricultural products from different countries. Information to guide the promotion of China's products and services in agricultural trade. In November 2015, in order to realize the interconnection of China's agricultural industry chain information, China began to run the e-commerce platform of "Eating globally", which is guided by "Internet+Agriculture" and established a distribution platform for the entire agricultural industry chain. We will improve the information transmission mechanism and achieve balanced supply and innovation in China's agricultural trade.

The cross-border e-commerce platform's improved information transmission and communication 
mechanism, rich and real-time information updates on agricultural products, and the convenient payment and settlement methods of the cross-border e-commerce platform have promoted the increase in small-scale cross-border agricultural product transactions. According to the statistics of Ali Research Institute, in 2013, the cross-border trade volume of agricultural products under Ali's e-commerce platform increased significantly, and the volume of export and import transactions increased by $80 \%$ and $60 \%$ year-on-year. In 2014, Ali's agricultural products sales resumed. New high sales of more than 48 billion yuan, an increase of $70 \%$ over 2013. The characteristics of small-lot and multi-batch agricultural products trade are very favorable to both enterprises and consumers. For enterprises, small batches and multiple batches mean that companies can flexibly allocate liquidity, reasonably control the risks of cross-border agricultural trade, and analyze the market's demand changes through customer's high-frequency purchases to adjust the company's marketing. Strategies; for consumers, the purchase of small agricultural products is conducive to meeting their diverse consumer needs, while the risk of cross-border purchases is also relatively low, so it is also more willing to try.

With the proliferation of service information and product information for agricultural trade in the global trading system, and the rapid development of global e-commerce platforms such as Amazon and eBay in global emerging markets, China's cross-border retail trade in agricultural products and opportunities for participating in international agricultural trade Rapid increase. With the growth of domestic cross-border e-commerce companies, cross-border e-commerce companies have also begun to extend to other parts of the cross-border marketing of agricultural products. The information flow, logistics, and capital flow of cross-border trade of agricultural products have been further integrated to promote agricultural products. Integration of trade. Increased trade integration capacity has made domestic and international agricultural trade more convenient, and barriers to entry of agricultural products have also been effectively reduced. This has not only made China's agricultural trade market more diversified, but also promoted the development of multilateral trade in agricultural products in China, Russia and Southeast Asia. The continuous emergence of markets in emerging countries such as India and India has changed the pattern of a single agricultural product that is dominated by European and American markets, and agricultural trade has expanded further into emerging countries.

\section{Constraints of the Development of Cross-border E-commerce Trade in Agricultural Products}

The cross-border e-commerce platform makes the buying and selling of agricultural products more convenient, but the complete trade of agricultural products also involves the logistics and transportation links. Different from domestic trade, cross-border agricultural products involve more trade policies than the main bodies of different regimes, and trade procedures are also more complex. There are many customs clearance procedures required for import and export, which makes the logistics cycle that cross-border agricultural trade needs to experience. This will inevitably have a negative impact on the quality of agricultural trade, and ultimately affect the development of cross-border e-commerce trade in agricultural products. On the other hand, cross-border fresh agricultural products and other agricultural products have stricter requirements for logistics support systems. The relevant cold chain logistics is needed to guarantee its quality. However, the current logistics infrastructure in our country is still relatively weak, the hardware supporting facilities required for cold chain logistics are even more lacking, and whether the supply chain is smoothly linked to the cross-border e-commerce trade of agricultural products. If it is successfully completed, it can be seen that the incompleteness of China's logistics guarantee system has no small limit on cross-border e-commerce trade in agricultural products.

International food trade attaches special importance to the quality and safety of food. Domestic agricultural products must use international cross-border e-commerce to reach overseas markets. They must meet the international agricultural product quality certification standards. This requires China's agricultural products exported by cross-border electricity suppliers to be tested according to international standards. However, the current level of internationalization of agricultural product 
hygiene standards in China is relatively low. The quality control system for agricultural products and the quality control system for agricultural products trade based on cross-border e-commerce are still unsound. Unsafe factors such as hormone residues and pesticide residues make agricultural products in China Trade is vulnerable to barriers to technical barriers to entry, thus affecting the development of agricultural trade. In addition, the lag in the construction of agricultural production bases in China means that the major agricultural products involved in cross-border e-commerce trade in agricultural products come from a large number of small and small farmers. The quality of these agricultural products will inevitably have a layered phenomenon, and this may cause agricultural products in our country. Trade suffers from a crisis of confidence, which in turn affects the export of agricultural trade.

Cross-border e-commerce trade in agricultural products takes the Internet as its main carrier, and thus it inherits the virtual and open nature of the Internet. This also amplifies the asymmetry of the information of trading entities, making agricultural trade prone to fraud and mistrust. At present, China's social social credit system has achieved good results, but the construction of laws and regulations on agricultural trade credit systems and cross-border e-commerce agricultural trade is still relatively backward. In addition, there are certain differences in the management systems and laws and regulations of cross-border e-commerce between countries. This has also led to problems such as false propaganda and lack of after-sales services for cross-border e-commerce trade in agricultural products. In the case of unsound credit systems, Consumers' privacy and interests in transactions are difficult to guarantee, which will affect the long-term development of cross-border e-commerce trade in agricultural products.

Under the background of the rapid development of cross-border e-commerce agricultural trade, comprehensive talents who understand both agricultural trade and e-commerce are very scarce. The talents required for cross-border e-commerce trade in agricultural products should be to master the domestic and foreign agricultural product industry, understand the agricultural product market, such as customer spending habits, product preferences, etc., and should also have e-commerce related technologies and knowledge, international trade settlement, and management innovation. Other aspects of capacity. However, the current education system in China has a large lag in the training and delivery of relevant talents, leading to a situation in which cross-border e-commerce industry personnel are in short supply. The shortage of comprehensive talents has caused great disadvantages to the operation and management of cross-border e-commerce. At the same time, the scarcity of high-end comprehensive talents may lead to the competition for talents among cross-border e-commerce companies, which will adversely affect the development of the entire industry. influences.

\section{Strategies for the Development of Cross-border E-commerce Trade in Agricultural Products}

Cross-border e-commerce enterprises should pay attention to the investment in the construction of logistics support system. Through the overall arrangement of storage centers, service centers, and distribution centers at home and abroad, an integrated logistics system for cross-border trade of agricultural products should be established, and the logistics system should be upgraded. The standardized operation level and informationization level will effectively improve the logistics assurance level of cross-border e-commerce agricultural trade. At the same time, cross-border e-commerce should continue to explore and improve logistics models based on the characteristics of cross-border trade of agricultural products in order to effectively improve the logistics competitiveness of cross-border trade of agricultural products.

Governments and enterprises should pay attention to synergies and formulate quality inspection standards applicable to cross-border e-commerce agricultural trade as soon as possible, and use the big data and cloud computing supported by cross-border e-commerce to continuously track the quality and origin of agricultural products to ensure agricultural products. Real-time monitoring of the quality of every link from production to the consumer. On the other hand, we should accelerate the promotion of real-name certification and credit rating for cross-border e-commerce enterprises 
that build agricultural trade, and timely disclose corporate credit information through public service platforms to reduce the phenomenon of asymmetric information on cross-border trade of agricultural products. At the same time, the government agencies should adopt judicial penalties for illegal cross-border e-commerce to protect the legal and orderly development of cross-border trade of agricultural products.

The improvement of the personnel training system requires the joint efforts of the government, educational institutions, and enterprises. On the one hand, the government should issue relevant policies to support the talent training market to carry out relevant talent training work. Institutions of higher education, talent training markets and other educational institutions should also actively cooperate with cross-border e-commerce companies to develop specialized talent training for their urgently needed talents. Projects; On the other hand, companies should pay attention to the cultivation of comprehensive talents and raise the level of benefits and promotion of talented people. This will attract external talents to participate in, and at the same time, it will also stimulate self-directed learning by employees, thus effectively relieving enterprises. Talent needs.

\section{References}

[1] Ma Shuzhong, Ren Wei, Wu Guojie. The characteristics of a country's agricultural product trade network and its influence on the division of global value chain: Based on the perspective of social network analysis [J]. Management World, 2016(03):60-72.

[2] Zhang Xiaheng, Guo Hailing. Cross-border e-commerce and cross-border logistics collaboration: mechanism and path [J]. China's circulation economy, 2016, 30 (11): 83-92.

[3] Xiong Qiquan, Deng Jiaqiong. Imbalance of China's Foreign Trade in Agricultural Products: Structure and Trend[J]. Journal of Huazhong Agricultural University (Social Science Edition), 2014(01):60-68.

[4] Tang Liwei. The Development Status of Cross-border E-Commerce Transaction and Foreign Exchange Management Policy: A Case Study of Cross-Border E-Commerce Development in Chengdu[J]. Southwest Finance, 2017(12):23-28.

[5] Xu Song, Zhang Yanyan. Cross-border e-commerce should be built into a new channel for “Made in China” exports. [J]. Economic and Trade Review, 2015(02):26-30. 